\title{
A new generation of cable grade poly(vinyl chloride) containing heavy metal free modifier
}

\author{
Ali I.Al-Mosawi ${ }^{1}$ [D
}

Received: 22 June 2021 / Accepted: 15 October 2021 / Published online: 9 December 2021

(c) The Author(s) 2021

\begin{abstract}
Many additives are used to improve the performance of cables in terms of increasing their flame retardancy, thermal stability, thermal conductivity, and other characteristics. Unfortunately, most of these additives contain heavy metals. Therefore, the main objective of this study is to introduce a material representing a new generation of environmentally friendly heavy metal-free stabilizers for cable grade poly(vinyl chloride) that can compete with traditional materials in terms of performance and distinctive properties. This unique additive is Oxydtron, a synthetic silicate or simply nanocement. The tests performed are rheological properties represented by a capillary rheometry analysis, limiting oxygen index, and volume resistivity. The most significant improvement in Bagley correction measurements was $14.61 \%$; $18.13 \%$; and $27.20 \%$ more than poly(vinyl chloride) basic formulation when using $5 \mathrm{wt} . \%$ Oxydtron at $160{ }^{\circ} \mathrm{C}, 170{ }^{\circ} \mathrm{C}$, and $180^{\circ} \mathrm{C}$, respectively. Also, the mean increases in relaxation time were 3.200 times, 8.825 times, and 12.458 times more than poly(vinyl chloride) basic formulation with $1 \mathrm{wt} . \%, 3 \mathrm{wt} . \%$, and $5 \mathrm{wt} . \%$ of Oxydtron, respectively. Furthermore, the Oxydtron lowered the value of the accompanying thermal gradient of the L.O.I test, reducing the heat-affected zone. The best result was with the extrusion processing method due to the uniformity of the processing conditions. However, the thermal gradient analysis showed residual heat stress in the test samples after cutting the burning layer and re-testing the samples again; this causes them to burn faster. This situation requires caution for designs that are exposed to high temperatures without burning. The optimum improvement in volume resistivity value was $14.71 \%$ and $38.24 \%$ more than poly(vinyl chloride) basic formulation after adding $5 \mathrm{wt} . \%$ and $7 \mathrm{wt} . \%$ of Oxydtron, respectively.
\end{abstract}

Keywords Cable grade $\cdot$ Oxydtron $\cdot$ Plasticized poly(vinyl chloride)

\section{Introduction}

It is well recognized that heavy metals are found in many additives used to improve the poly(vinyl chloride) performance, such as stabilizers and flame retardants. Despite their environmental and health threats, they are now widely used [1-5]. The accumulation of these heavy metals from stabilizers and flame retardants in soil, water (whether in rivers, lakes, groundwater), or even in the air leads to environmental pollution, leading to flame retardant transfer to organisms in that polluted environment, including humans. For example, in European countries, concentrations of flame retardants were found in human milk and the bodies

Ali I.Al-Mosawi

alialmosawi76@gmai.com; aliibrahim76@yahoo.com

1 Institute of Ceramic and Polymer Engineering, University of Miskolc, Miskolc, Hungary of birth cohorts (but their concentrations were lower than in the United States) and household dust. Concentrations of flame retardants were also found in the bodies of birds and their eggs [6-14]. Therefore, accountable to these environmental challenges and responsibilities, most of these flame retardants must be reconsidered in terms of use and finding an environmentally friendly and sustainable alternative. Especially since countries have already started issuing laws prohibiting the use of certain types of flame retardants due to their severe damage to the environment after research has proven this [15-17]. Many flame retardants currently in use are included in European Union regulation (EC) No. $1272 / 2008$ and its amendments for materials classification, classified as dangerous materials. So it has become imperative to search for safe alternatives to these materials [18]. Therefore, there must be a precise harmony between environmentally friendly flame retardants and preserving the materials' properties. This matter requires more time and 
research for a complete shift from traditional flame retardants to those environmentally friendly [1, 18-21]. Certain recent flame retardants are now available to comply with the successful flammability tests regulations. Also, the interference of retardants with flame reaction chains will restrict the oxidation of the hydrocarbon. This interference will prevent the process of converting carbon monoxide to carbon dioxide, which causes highly volatile, very smoky fire effluents and rich in incomplete combustion products [22]. On the other hand, a significant effort has been made in recent years to develop new stabilization systems for poly(vinyl chloride) processing to get as far away as possible from heavy metal-based stabilizers. Due to the toxicity of the lead and cadmium stabilizers, they are now in limited use, but despite there are various alternatives now to occupy a place of these stabilizers, such as calcium/zinc, organotin, and barium/zinc systems, but still has its disadvantages for the plasticized vinyl formulator.

Therefore, a complete switch to environmentally friendly stabilizers needs more research in this field. With the tendency to replace traditional stabilizers and flame retardants with environmentally friendly ones, the environmental conditions surrounding the product containing this type of stabilizers and retardants must be considered and the applications for which it is used. One study revealed that environmentally friendly retardants could be harmful when breaking down by heat and ultraviolet rays [22-24]. Therefore, it is necessary to use these retardants carefully. Obtaining the ideal flame retardant requires great research efforts that may not take as long as previous research due to scientific research development. Simultaneously, the chemical stability of environmentally friendly stabilizers and flame retardants in different conditions is critical to increasing safety levels when using these retardants.

\section{Experimental procedure}

\section{Materials}

There are two types of materials used in this article:

1. The essential components of PVC: These are the mixture materials necessary to form the PVC basic formulation after processing, which consists of:

i. The suspension powder: which is the main component of the mixture. Ongrovil® S-5070 suspension type PVC produced and supplied by BorsodChemZrt., Hungary, was used in my work with a quantity of $100 \mathrm{phr}$. ii. Plasticizer: This material aims to give sufficient flexibility to the product, and here a DOP (or DEHP), Bis(2-Ethylhexyl) ortho-phthalate Plasticizer was used with a quantity of $70 \mathrm{phr}$. DEZA, a. s, CO., Valašské Meziříčí, Czech Republic supplies this Plasticizer.

iii. Stabilizer: and its purpose is to improve PVC resistance for many functional conditions. Newstab-50® Calcium-Zinc-based stabilizer supplied by Betaquímica CO., Spain, was used for this purpose with a quantity of $1.5 \mathrm{phr}$.

iv. Lubricant: this material helps facilitate PVC processing through reducing friction and sheardependent viscosity control. Licowax ${ }^{\circledR} \mathrm{E}$ Wax supplied by Clariant International Ltd, Muttenz Switzerland, was used in this work with a quantity of $0.3 \mathrm{phr}$.

2. Additive: To improve specific properties in any polymer, many additives are added. In this article, Oxydtron ${ }^{\circledR}$ Nanocement-type A, an environmentally friendly heavy metal-free, has been added with three different quantities 1, 3, and 5 wt.\%. Bioekotech Hungary Kft supplied Oxydtron ${ }^{\circledR}$ Nanocement.

\section{Mixing process}

All the materials (except Oxydtron) had been mixed by a high-speed fluid mixer type Mischtechnik MTI 10. After the mixing process begins, the temperature increases steadily from room temperature to $150{ }^{\circ} \mathrm{C}$ due to the shearing of particles between the components, rising from 600 to $2700 \mathrm{rpm}$. The mixture stays at $2700 \mathrm{rpm}$ for about $15 \mathrm{~min}$ while the temperature increases to $150{ }^{\circ} \mathrm{C}$. It allows the plasticizer to completely penetrate poly(vinyl chloride) particles to achieve a homogenized structure and optimum manufacturing characteristics. The mixing speed is then decreased to $600 \mathrm{rpm}$, cooling water is circulated in the jacket of the mixer, and the temperature drops below $45^{\circ} \mathrm{C}$. The mixture stays at this temperature and speed until the mixing phase is completed. It takes about $40 \mathrm{~min}$ to complete the mixing process. After the main mixing phase, Oxydtron is applied to the basic formulation mixture of poly(vinyl chloride) by weight fraction $(1,3$, and $5 \mathrm{wt} . \%)$ and mixed in a small electrical mixer to uniformly dispersed and homogenized into sample powder mixtures.

\section{Preparation of samples}

In all tests, Four blends of plasticized poly(vinyl chloride) had been made, (1) poly(vinyl chloride) basic formulation; (2) poly(vinyl chloride) containing $1 \mathrm{wt} . \%$ Oxydtron; (3) 
poly(vinyl chloride) containing 3wt.\% Oxydtron; and (4) poly(vinyl chloride) containing 5wt.\% Oxydtron. All samples have been prepared according to ISO standards, and all preparation steps have been completed at BorsodChem Zrt., Hungary as follows:

1. Capillary Rheometry Analysis Samples: the samples were produced by using extrusion machine type SCHLOEMANN BT-50 as a disk shape with $3 \mathrm{~mm}$ diameter and $2 \mathrm{~mm}$ thickness.

2. Limiting Oxygen Index Samples (L.O.I): L.O.I samples were fabricated as a rod by using an extrusion machine type GÖTTFERT with $170{ }^{\circ} \mathrm{C}$ temperature and $60 \mathrm{rpm}$ speed.

3. Volume Resistivity Samples: these samples were prepared by using laboratory roll mill type Schwabenthan polymix $150 \mathrm{U}$, at $170{ }^{\circ} \mathrm{C}$ temperature, time $5 \mathrm{~min}$, rolling speeds $21 \mathrm{rpm}$ (front roller) and $24 \mathrm{rpm}$ (back roller). The samples have a circular shape with $70 \mathrm{~mm}$ diameter and $1 \mathrm{~mm}$ thickness.

\section{The tests}

\section{The capillary rheometry analysis}

This test was done at BorsodChem Zrt. And according to ISO 11443:2014 standard [25], at different temperatures rang $\left(160^{\circ} \mathrm{C}, 170^{\circ} \mathrm{C}\right.$, and $\left.180^{\circ} \mathrm{C}\right)$ and different dies lengths $(15,30$, and $45 \mathrm{~mm})$ with $(3 \mathrm{~mm})$ die hole diameter for all lengths. Laboratory extruder type Göttfert Extrusiometer G20 was used to complete this test with a processing speed of $60 \mathrm{rpm}$. Capillaries rheometer tests are often achieved by applying pressure above the capillary inlet. Therefore, an additional pressure drop at the die entrance hides the true pressure drop along the capillary, where the flowing material goes from a wide reservoir (the main cylinder or barrel) to a narrow capillary, possibly also generating turbulence. Assuming that the same extra pressure drop occurs with different capillary lengths (but maintaining a constant barrel and capillary diameter and inlet shape), the pressure reading can be corrected, and the true pressure drop can be estimated much more accurately. The state called Bagley correction.

\section{Limiting oxygen index test}

L.O.I test was done according to ISO 4589-2 standard [26] by using a Stanton Redcroft FTA flammability unit at BorsodChem Zrt., Hungary; Laboratory of Vinyl Technology.

\section{Relaxation time measurement}

DMA test results were used to calculate the relaxation time. The DMA test was done according to ISO 6721-11:2012 standard [27] by using dynamic mechanical, thermal analyzer MK III manufactured by Rheometric Scientific, Inc. and found at BorsodChem Zrt., Hungary, used for testing the samples.

\section{Volume resistivity measurement}

IM6 Megohmmeter Radiometer Copenhagen manufactured by RE Instruments was used to record the volume resistivity of samples according to ASTM D257-14 standard [28]. This device is found at BorsodChem Zrt., Hungary.

\section{FLIR thermal gradient image analysis}

Thermal analysis for L.O.I samples by using a thermal imaging camera (FLIR Systems) has been done to determine the thermal gradient of HAZ The image and object parameters of this analysis are shown in Table 1.

\section{SEM-EDX analysis}

SEM-EDX analysis was used to analyze the chemical composition of Oxydtron and the dispersion of this additive in the poly(vinyl chloride). This test was carried out using a Carl Zeiss EVO MA10 SEM at the University of Miskolc. The results of SEM-EDX analysis are shown in Fig. 1, which represents the chemical composition analysis for Oxydtron, Fig. 2 represents the SEM images for dispersion Oxydtron in the poly(vinyl chloride). Finally, Fig. 3 represents the EDX mapping analysis for poly(vinyl chloride) containing Oxydtron.

\section{Results and discussion}

\section{Capillary rheometry analysis}

It is known that the inlet pressure drop $(\Delta \mathrm{p})$ can be measured practically by using capillaries that are of different lengths while maintaining a constant diameter. And in the case of round hole capillaries, the Bagley correct is required to measure this inlet pressure drop [29-31]. Figure 4 represents the length correction of plasticized poly(vinyl chloride) basic formulation at speed $60 \mathrm{rpm}$, accomplished with

Table 1 Image and object parameters of FLIR analysis

\begin{tabular}{ll}
\hline Parameter & Description/ Value \\
\hline Camera Model & FLIR SC660 \\
Emissivity & 0.5 \\
Reflected apparent temperature & $20^{\circ} \mathrm{C}$ \\
Object distance & $1.0 \mathrm{~m}$ \\
\hline
\end{tabular}




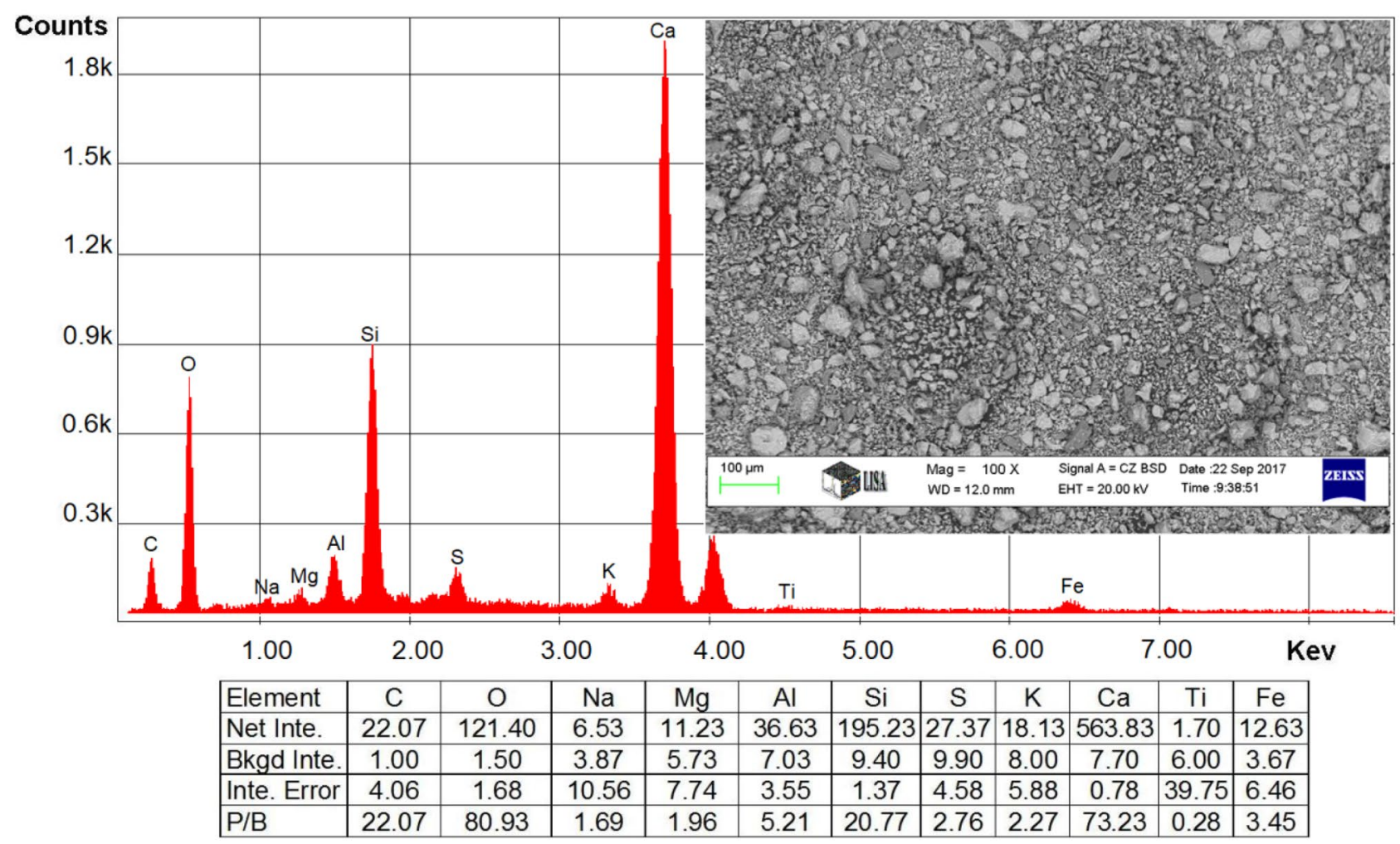

Fig. 1 SEM- EDX analysis for Oxydtron

three different capillaries length $(15,30$, and $45 \mathrm{~mm})$ have the same diameter $(3 \mathrm{~mm})$ and $(\mathrm{L} / \mathrm{D})$ were $(5,10,15)$. And Table 2 represents Bagley correction and slope values of plasticized poly(vinyl chloride) basic formulation at the same three temperatures. As the plasticized poly(vinyl chloride) melt travels and is extruded from the greater diameter of the barrel to the smaller diameter of the capillary, the excess pressure begins to drop due to extensional viscosity $[32,33]$. The pressure drop is proportional to the capillary length, which is more significant with the longer capillary. However, it is inversely proportional to the temperature as the higher the temperature, the lower the pressure drop. This condition is also similar to the Bagley correction, as shown in Table 2. The length correction will decrease with increasing the temperature because the poly(vinyl chloride) melt becomes less elastic at higher temperatures. Also, We can observe from this figure that the extrapolation of the linear Bagley correction plots of poly(vinyl chloride) basic formulation indicated an excellent fitting.

Figure 5 represents the length correction of plasticized poly(vinyl chloride) containing $1 \mathrm{wt}$. \% Oxydtron at $160{ }^{\circ} \mathrm{C}, 170{ }^{\circ} \mathrm{C}$, and $180^{\circ} \mathrm{C}$, respectively, at speed $60 \mathrm{rpm}$. Table 3 represents the Bagley correction and slope values for poly(vinyl chloride) containing $1 \mathrm{wt} . \%$ Oxydtron at the same temperature and speed. This figure and the table show that the Bagley correction value has increased after adding
Oxydtron. It is a fact that the shear stress is directly proportional to the pressure drop [34-36]; therefore, the shear stress values in the case of plasticized poly(vinyl chloride) containing $1 \mathrm{wt} . \%$ Oxydtron will be higher than poly(vinyl chloride) basic formulation. Still, the higher correction values show higher melt elasticity, and it can be evident that the length correction could be the measure of melt elasticity. For that, I didn't find any references. Also, through Fig. 3 we observe that the fitting will be much better, and the slope values are higher than in poly(vinyl chloride) basic formulation, where the particles will increase the shear stress because it is an effective filler in terms of mechanical properties. We also found that the plasticized poly(vinyl chloride) containing Oxydtron is less sticky to the exit mold hole, which will happen to the extrusion barrel, reducing the viscosity of the melt.

With an increase in the weight fraction of Oxydtron to $3 \mathrm{wt} . \%$, the improvement of length correction increases, which is what we can see in Fig. 6, which represent the Bagley correction for of plasticized poly(vinyl chloride) containing 3 wt. $\%$ Oxydtron at $160{ }^{\circ} \mathrm{C}, 160{ }^{\circ} \mathrm{C}, 170{ }^{\circ} \mathrm{C}$, and $180^{\circ} \mathrm{C}$ respectively. The Bagley correction and slope values for poly(vinyl chloride) containing $3 \mathrm{wt}$.\% Oxydtron at the same temperature and speed are presented in Table 4.

There has also been an improvement in the drop in pressure, which means that the melt's elasticity has 

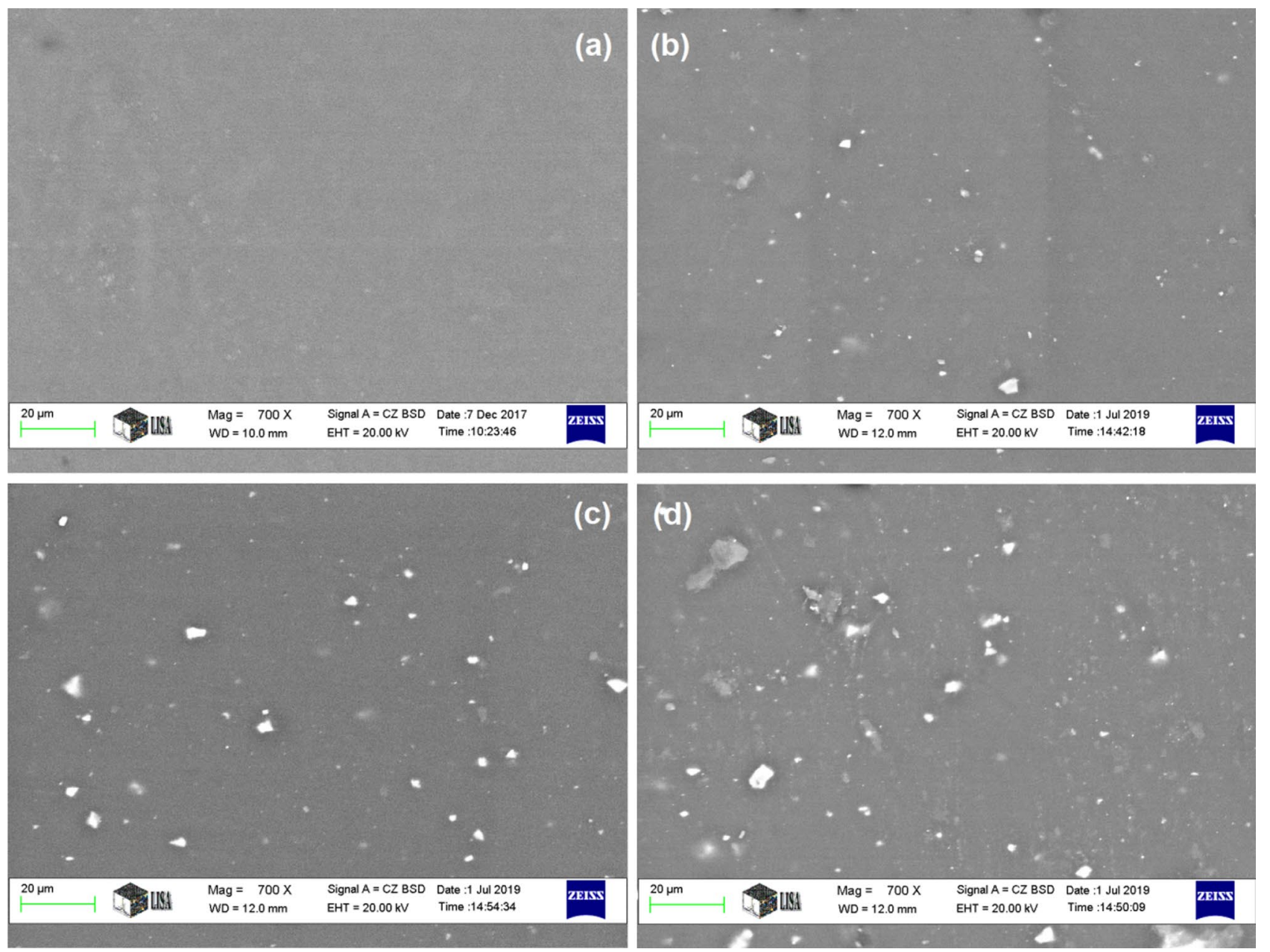

Fig. 2 SEM analysis images for dispersion of Oxydtron in the poly(vinyl chloride), where (a) Poly(vinyl chloride) basic formulation, (b), (c), and (d) Poly(vinyl chloride) containing $1 \mathrm{wt} . \%, 3 \mathrm{wt} . \%$, and 5wt.\%, Oxydtron respectively

improved further, as explained earlier. Although the length correction continues to decrease with increasing temperatures (which is normal), it maintains higher accuracy levels than the poly(vinyl chloride) basic formulation or containing 1wt.\% Oxydtron. This is possibly the key reason why Oxydtron is so successful because of this additive's role in counteracting the segmental movement, and the polymer structure will consist of liquidlike molecules that increase the elasticity.

The perfect results were achieved in the length correction enhancement by applying 5\% Oxydtron, which can be seen in Fig. 7, which display the Bagley correction for plasticized poly(vinyl chloride) containing $5 \mathrm{wt} . \%$ Oxydtron at $160{ }^{\circ} \mathrm{C}$, $160{ }^{\circ} \mathrm{C}, 170{ }^{\circ} \mathrm{C}$, and $180{ }^{\circ} \mathrm{C}$ respectively, and in Table 5 . The Oxydtron continues to sustain a high degree of length correction as the additional percentage increases to $5 \mathrm{wt} . \%$.

Also, we can see from Fig. 8, which represents Bagley correction as a function of Oxydtron weight fraction, that the Bagley correction increases with increasing Oxydtron addition. Even 1wt.\% of Oxydtron significantly improves the Bagley correction and adding further Oxydtron continues to rise. That means the additive increased the melt elasticity. The poly(vinyl chloride) melt elasticity increases by increasing temperature, and the viscous flow becomes dominant. Because the Bagley correction represents the energy necessary to alter the flow geometry, the Bagley correction of the plasticized poly(vinyl chloride) decreases by increasing temperature. But this drop in Bagley correction will be less in the presence of Oxydtron, as shown in Fig. 9, which represents Bagley correction as a function of the processing temperature.

\section{Relaxation time}

As we know, the relaxation time in polymers represents the time required for polymer chains to return to equilibrium after deformation, where substantial mobility in the polymer's structure has happened [37-39]. 


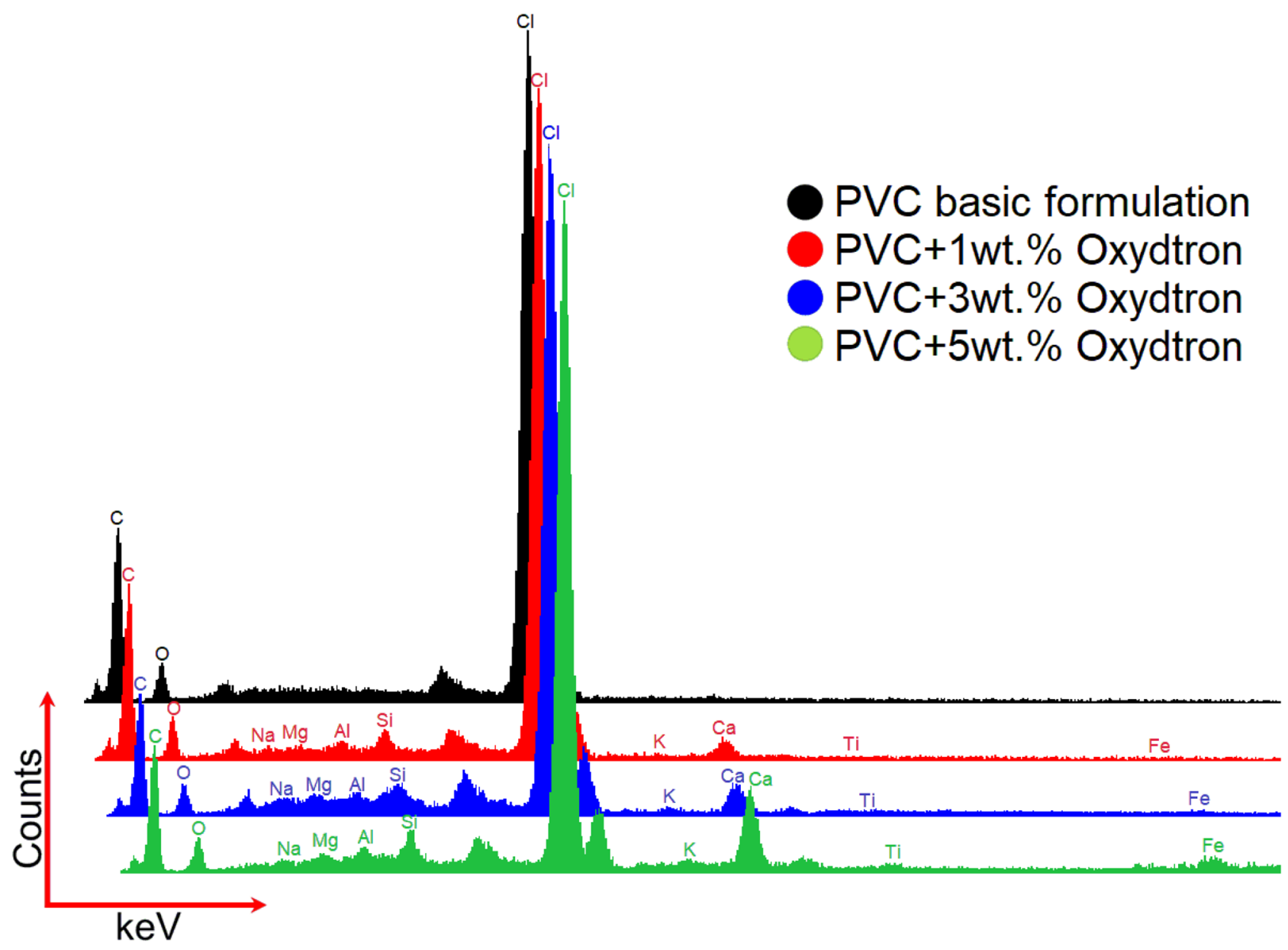

Fig. 3 EDX mapping analysis for poly(vinyl chloride) containing Oxydtron

Fig. 4 Length or Bagley correction of for plasticized poly(vinyl chloride) basic formulation at $160{ }^{\circ} \mathrm{C}, 170{ }^{\circ} \mathrm{C}$, and $180{ }^{\circ} \mathrm{C}$ respectively

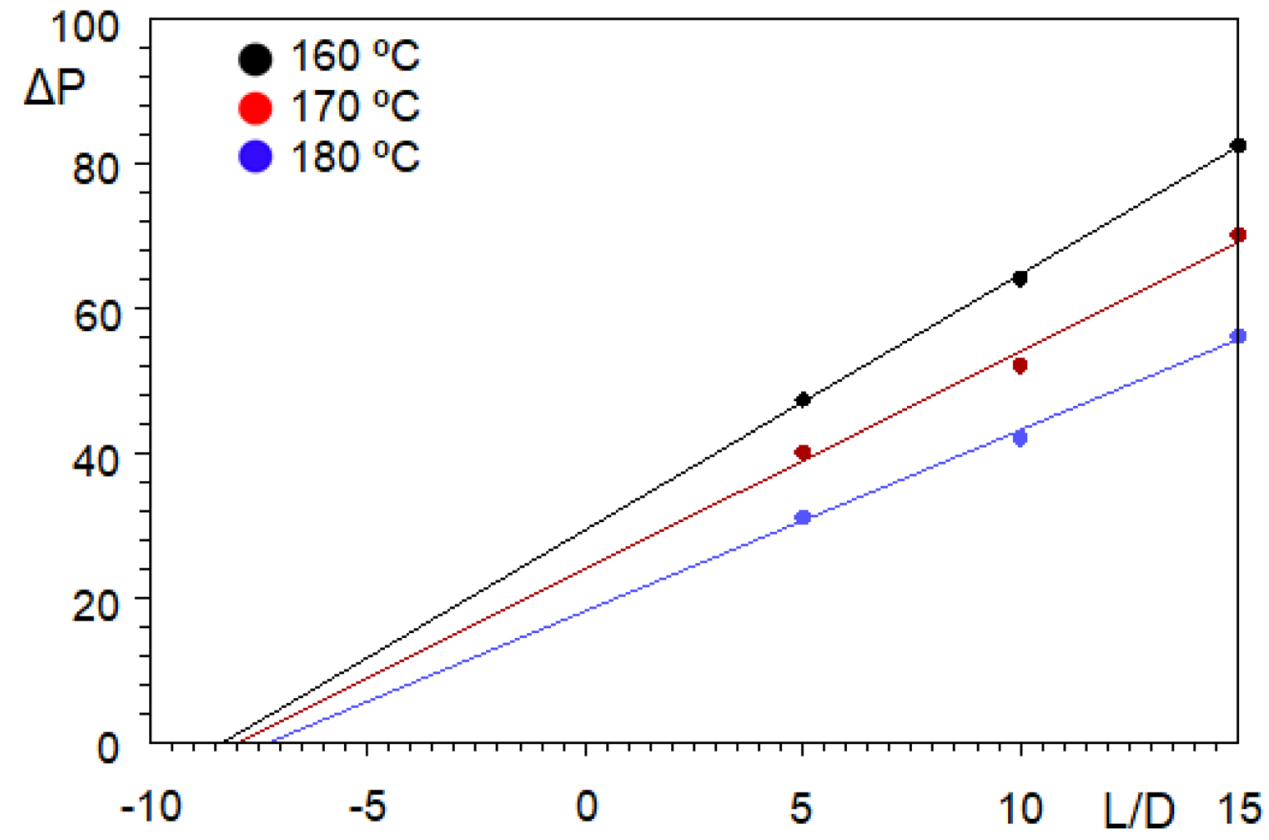


Table 2 Bagley correction and slope values of plasticized poly(vinyl chloride) basic formulation at $160{ }^{\circ} \mathrm{C}, 170{ }^{\circ} \mathrm{C}$, and $180{ }^{\circ} \mathrm{C}$

\begin{tabular}{llll}
\hline Temperature, ${ }^{\circ} \mathrm{C}$ & 160 & 170 & 180 \\
\hline Bagley Correction & 8.35 & 8.00 & 7.28 \\
Slope & 3.52 & 3.00 & 2.49 \\
\hline
\end{tabular}

Figure 10 represents the relaxation time $(\tau)$ for plasticized poly(vinyl chloride) containing Oxydtron, calculated based on the temperature test data with temperatures range $-20{ }^{\circ} \mathrm{C},-10{ }^{\circ} \mathrm{C}$, and $0{ }^{\circ} \mathrm{C}$. Evidently, $\tau(\mathrm{T})$ (relaxation time at $\mathrm{T}$ temperature) is independent of frequency; the temperature of maxima is shifted to higher temperatures by increasing frequency because shorter relaxation time appears at the higher temperature. Also, we can see that the relative increase of relaxation time is almost linear by Oxydtron content, as shown in Fig. 11, and at 5wt.\% Oxydtron reached 12 times (12.458) more than poly(vinyl chloride) basic formulation. The relative increase is the same at different temperatures.

From Table 6 which represents the glass transition temperatures ( $\mathrm{Tg}$ ) values for plasticized poly(vinyl chloride) containing Oxydtron, we can see that there is an interaction between poly(vinyl chloride) and Oxydtron particles, which causes the reduction of the kinetic energy of plasticized poly(vinyl chloride), and reducing the segmental movement as mentioned, which will prevent the molecules from assembling in crystalline systems, so the relaxation time of this movement increases and the polymer will consist of long physically crosslinked liquid-like molecules [37].
Table 3 Bagley correction and slope values of plasticized poly(vinyl chloride) containing $1 \mathrm{wt} . \%$ Oxydtron at $160{ }^{\circ} \mathrm{C}, 170{ }^{\circ} \mathrm{C}$, and $180{ }^{\circ} \mathrm{C}$

\begin{tabular}{llll}
\hline Temperature,${ }^{\circ} \mathrm{C}$ & 160 & 170 & 180 \\
\hline Bagley Correction & 9.10 & 9.07 & 8.90 \\
Slope & 3.64 & 3.04 & 2.38 \\
\hline
\end{tabular}

\section{Volume resistivity ( $\rho)$}

The cable cover material must have high electrical insulation properties conjugated with high flammability resistance, providing maximum protection and safety levels [40-43]. Figure 12 represents the electrical behavior (volume resistivity- $\rho$ ) of plasticized poly(vinyl chloride) containing Oxydtron. From this figure, we can notes that the Oxydtron increased the volume resistivity, i.e., decreased the conductivity, where the increase in resistivity is directly proportional to the percentage of Oxydtron. Because silicate compounds might contain imperfect structures, both anions and cations are fixed to the crystal lattice. Therefore, these immobile ions cannot neutralize each other better, trapping mobile ions from the matrix polymer. The effect is utilized using calcined clay filler, improving the electrical properties of PVC compounds. Since the Oxydtron is a clay-based product, it can be assumed that it works similarly.

\section{SEM and thermal gradient analysis for heat affected zone (HAZ)}

Despite the fact that poly(vinyl chloride) has a superior flame resistance compared to other polymers, it will suffer
Fig. 5 Length or Bagley correction for of plasticized poly(vinyl chloride) containing $1 \mathrm{wt} . \%$ Oxydtron at $160^{\circ} \mathrm{C}, 170{ }^{\circ} \mathrm{C}$, and $180{ }^{\circ} \mathrm{C}$ respectively

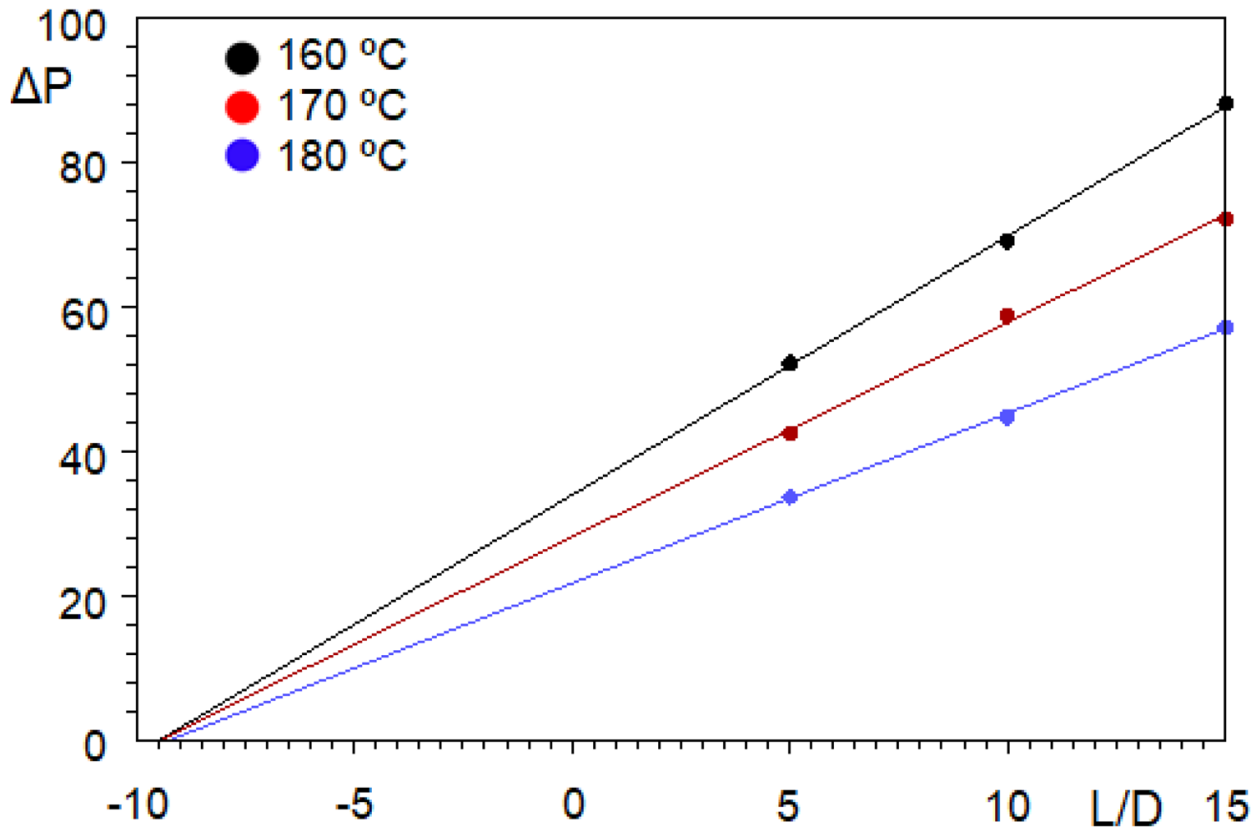


Fig. 6 Length or Bagley correction for of plasticized poly(vinyl chloride) containing $3 \mathrm{wt} . \%$ Oxydtron at $160^{\circ} \mathrm{C}, 170{ }^{\circ} \mathrm{C}$, and $180{ }^{\circ} \mathrm{C}$ respectively

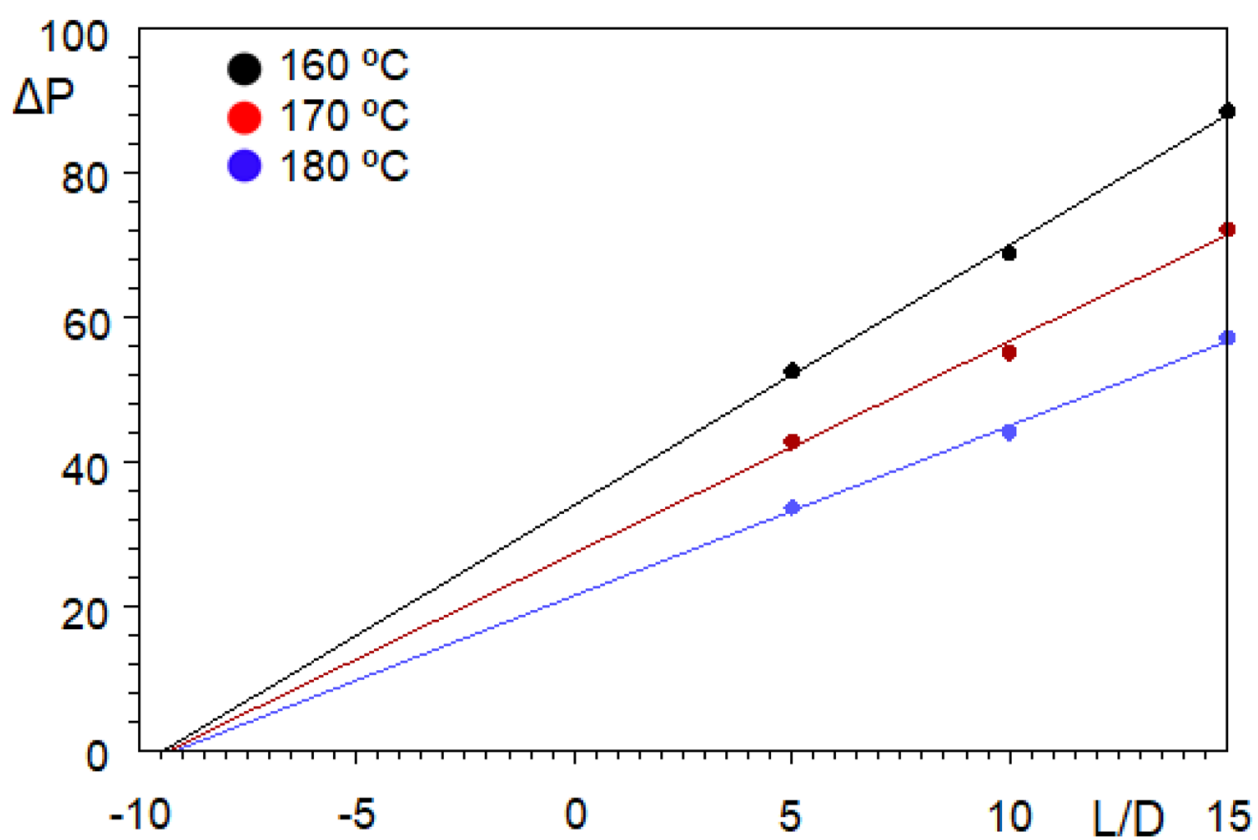

Table 4 Bagley correction and slope values of plasticized poly(vinyl chloride) containing $3 \mathrm{wt} . \%$ Oxydtron at $160^{\circ} \mathrm{C}, 170^{\circ} \mathrm{C}$, and $180{ }^{\circ} \mathrm{C}$

\begin{tabular}{llll}
\hline Temperature, ${ }^{\circ} \mathrm{C}$ & 160 & 170 & 180 \\
\hline Bagley Correction & 9.44 & 9.31 & 9.17 \\
Slope & 3.60 & 2.93 & 2.34 \\
\hline
\end{tabular}

from structural changes due to exposure to high temperatures, which causes deterioration of its distinctive properties [44-49]. The poly(vinyl chloride) structure will begin to release $\mathrm{HCl}$ from its internal structure at elevated temperatures, i.e., it begins to degrade in these temperatures. Thus, the poly(vinyl chloride) structure will lose $\mathrm{HCl}$, not just from burnt layers directly exposed to fire. Still, this loss of chlorine-containing compounds extends to the under layers far from the combustion zone, which I called heat-affected zone (HAZ), as shown in Fig. 13. This behavior is due to the dehydrochlorination of poly(vinyl chloride). Through Fig. 13a we notice that the heataffected zone is wide in poly(vinyl chloride) basic formulation, which is evidence of its low thermal and flame
Fig. 7 Length or Bagley correction for of plasticized poly(vinyl chloride) containing $5 \mathrm{wt} . \%$ Oxydtron at $160^{\circ} \mathrm{C}, 170{ }^{\circ} \mathrm{C}$, and $180^{\circ} \mathrm{C}$ respectively

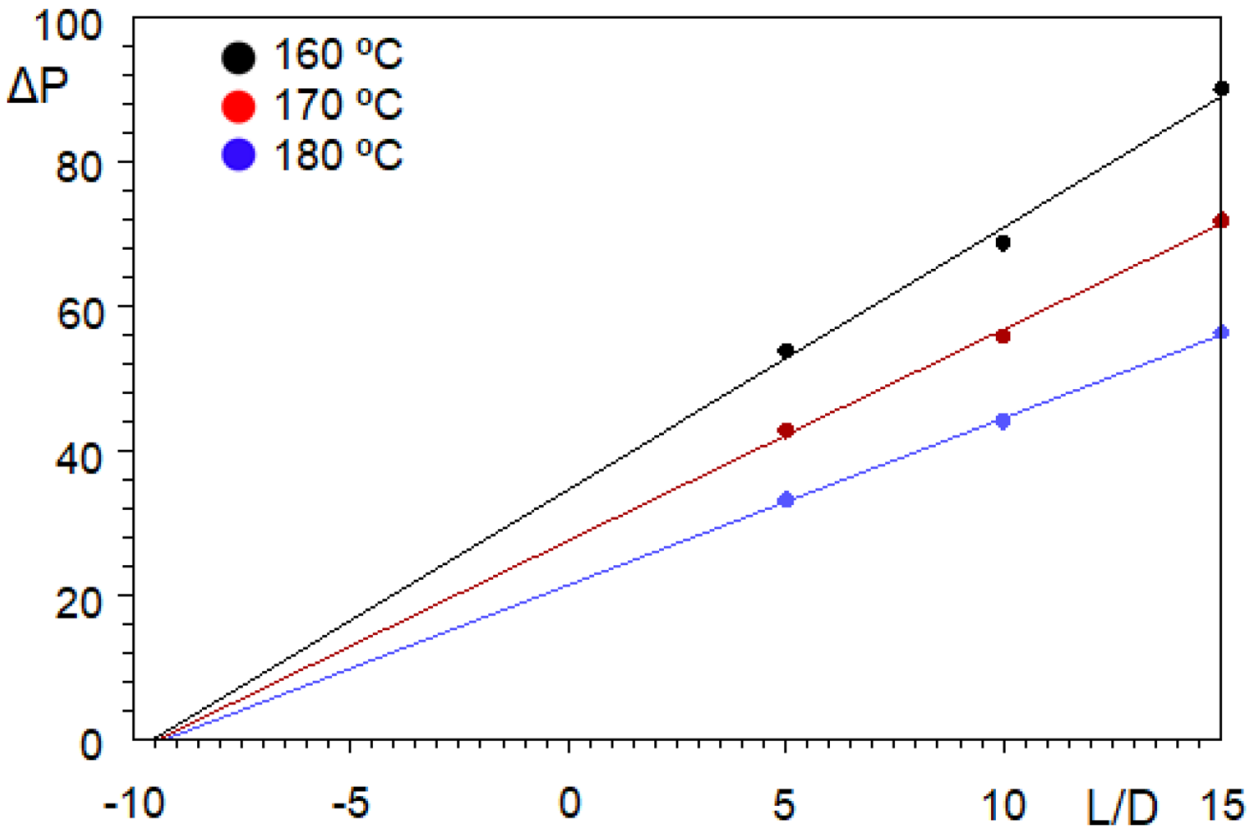


Table 5 Bagley correction and slope values of plasticized poly(vinyl chloride) containing $5 \mathrm{wt} . \%$ Oxydtron at $160{ }^{\circ} \mathrm{C}, 170{ }^{\circ} \mathrm{C}$, and $180{ }^{\circ} \mathrm{C}$

\begin{tabular}{llll}
\hline Temperature, ${ }^{\circ} \mathrm{C}$ & 160 & 170 & 180 \\
\hline Bagley Correction & 9.57 & 9.45 & 9.26 \\
Slope & 3.62 & 2.92 & 2.31 \\
\hline
\end{tabular}

resistance and its rapid degradation at high temperatures of heating or combustion. The actual change in this critical zone begins after the addition of $1 \mathrm{wt} . \%$ Oxydtron, as shown in Fig. 13b. The FLIR imaging test showed the beginning of the receding of the thermal effect in this zone than before adding the Oxydtron, leading to an increase in the thermal stability of the poly(vinyl chloride). The HAZ recedes further with the rise in the weight fraction of Oxydtron to $3 \mathrm{wt} . \%$ and $5 \mathrm{wt} . \%$ as shown in Fig. 13c, d, resulting in increased resistance and stability of the poly(vinyl chloride) at such high temperatures, which reduces the degradation risk.

Also, I found that when re-testing the same sample again after cutting the burned area, the under layers have been ignited faster, and the HAZ area is wider, as shown in Fig. 14. This behavior was dissimilar to the original sample tested for the first time, which means the heat-affected layer has low flame resistance due to less chlorine [50].
Fig. 8 Bagley correction as a function of Oxydtron wt.\% at $160{ }^{\circ} \mathrm{C}, 170{ }^{\circ} \mathrm{C}$, and $180{ }^{\circ} \mathrm{C}$ respectively

Fig. 9 Bagley correction as a function of processing temperature
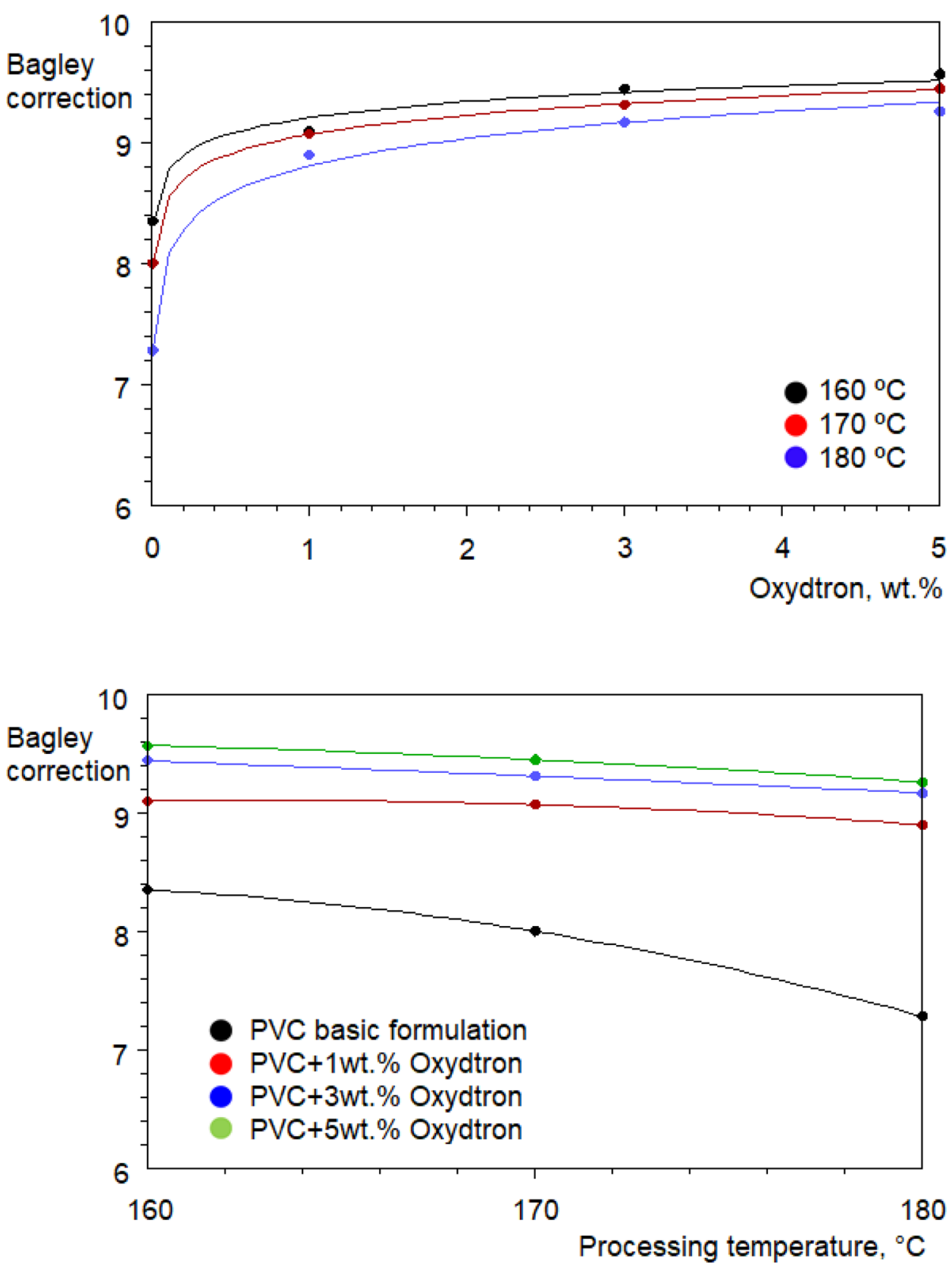
Fig. 10 The relaxation time for plasticized poly(vinyl chloride) containing Oxydtron as a function of temperature
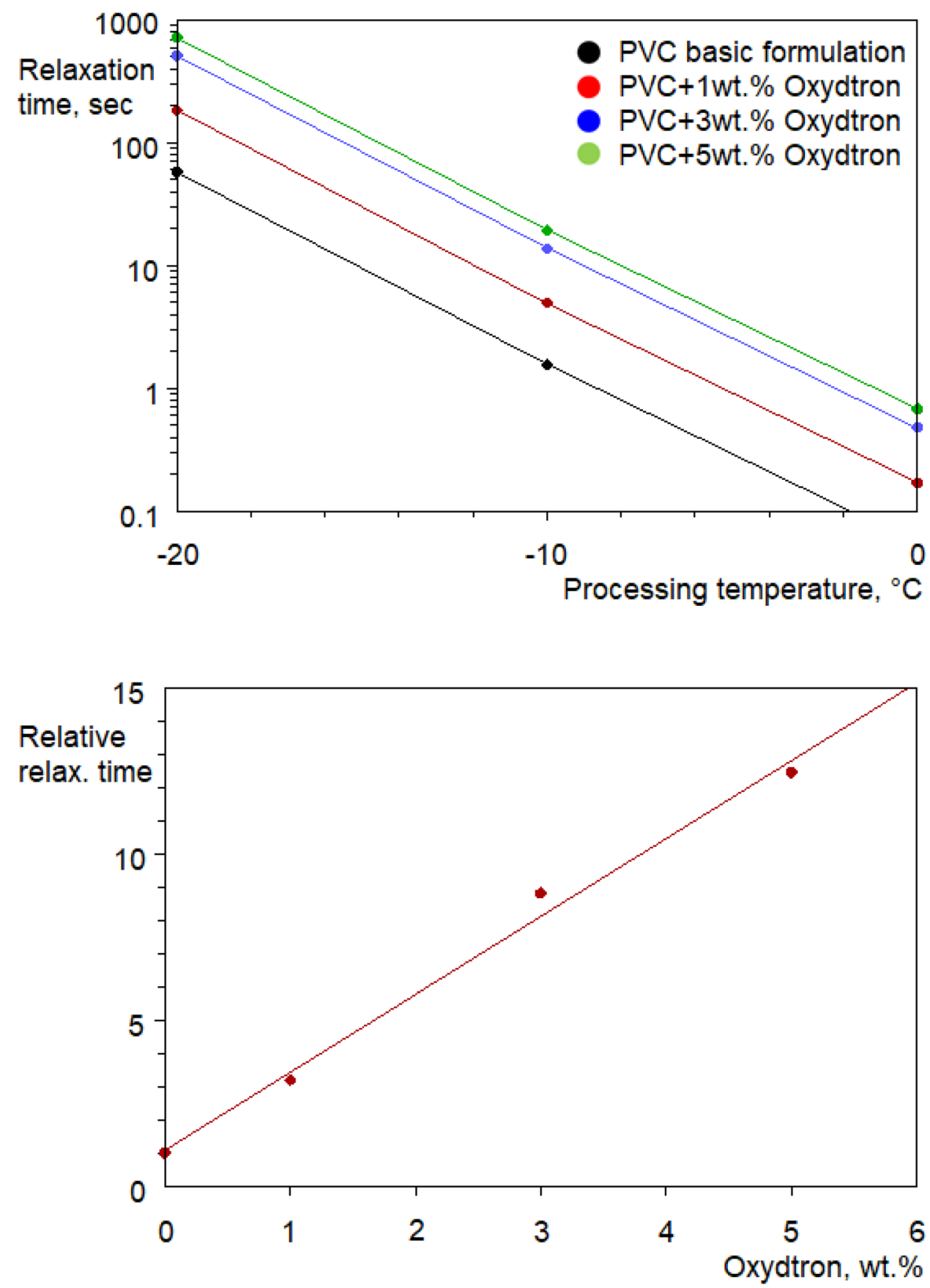

Fig. 11 The relative relaxation time as a function of Oxydtron content
The size of the heat-affected zone depends on the type of processing method, as it is wider in rolling samples than in extrusion samples, as shown in Fig. 15. Since the rolling sample is exposed to processing temperatures more

Table 6 Glass transition temperatures $\left(T_{g}\right)$ measured by DMA for plasticized poly(vinyl chloride) containing Oxydtron

\begin{tabular}{lllll}
\hline Material & PVC & $\begin{array}{l}\text { PVC }+1 \% \\
\text { Oxydtron }\end{array}$ & $\begin{array}{l}\text { PVC }+3 \% \\
\text { Oxydtron }\end{array}$ & $\begin{array}{l}\text { PVC }+5 \% \\
\text { Oxydtron }\end{array}$ \\
\hline $\mathrm{Tg},{ }^{\circ} \mathrm{C}$ & -3.60 & 0.30 & 3.50 & 4.66 \\
\hline
\end{tabular}

prolonged than the one-stage extrusion, the rolling sample is more heat stressed. Also, the rolling temperature is irregular along the length of the roll, which causes the concentration of the elements to varying from one point to another depending on the amount of heat that was exposed during the rolling. This thing will accelerate its yielding and softening when exposed to fires, unlike the extrusion sample, which resists fires better. Therefore, it is necessary to pay attention to the correct selection of the processing method in applications requiring high flame resistance. 
Fig. 12 Volume resistivity of plasticized poly(vinyl chloride) containing Oxydtron

Fig. 13 FLIR analysis for HAZ after L.O.I test in (a) PVC basic formulation, (b) PVC + 1wt.\% Oxydtron, (c) PVC + 3wt. \%

Oxydtron, and (d) PVC + 5wt.\% Oxydtron
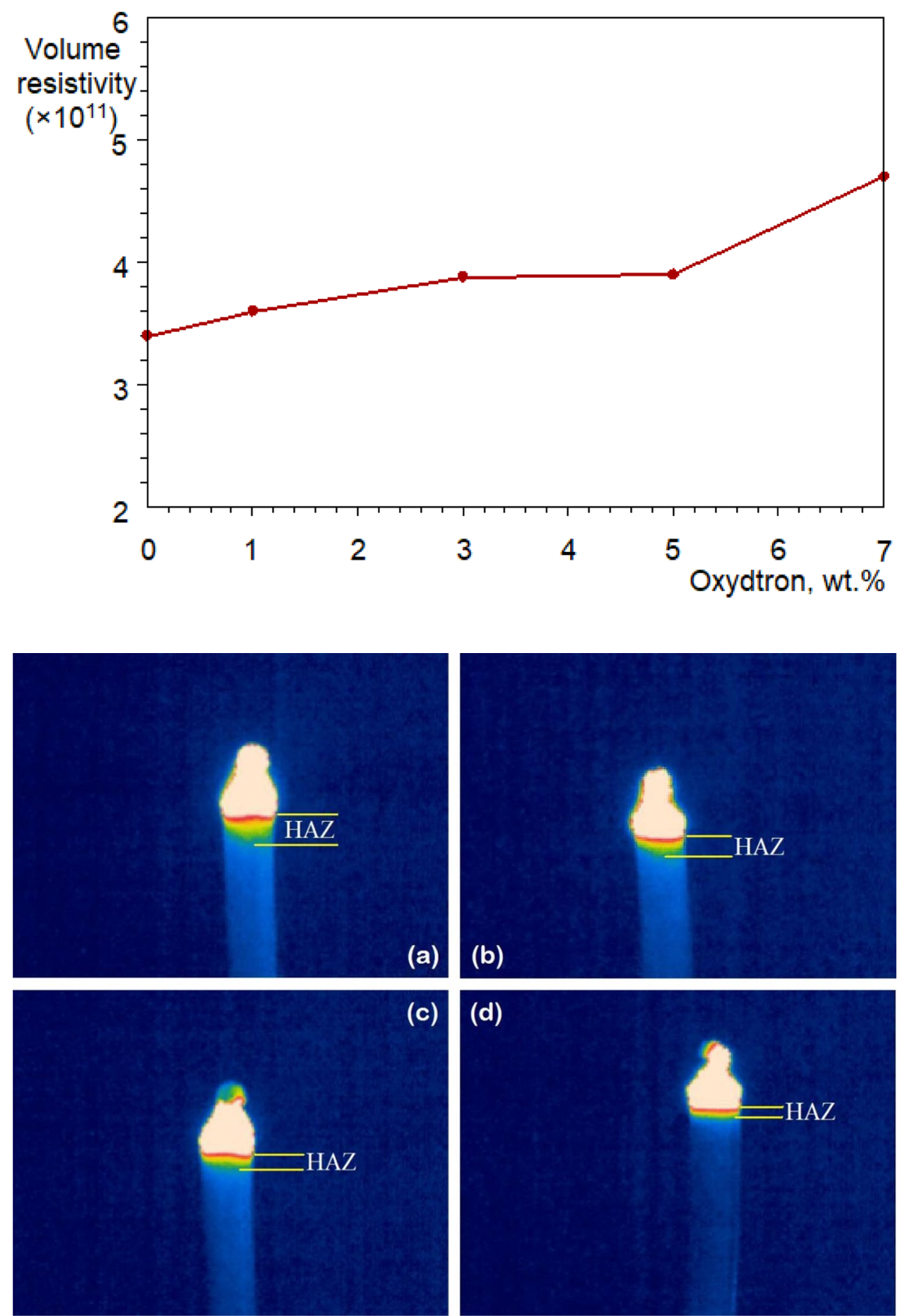
Fig. 14 FLIR for extruded plasticized poly(vinyl chloride) basic formulation HAZ when (a) testing for the first time, (b) re-testing after cutting the burnt layer
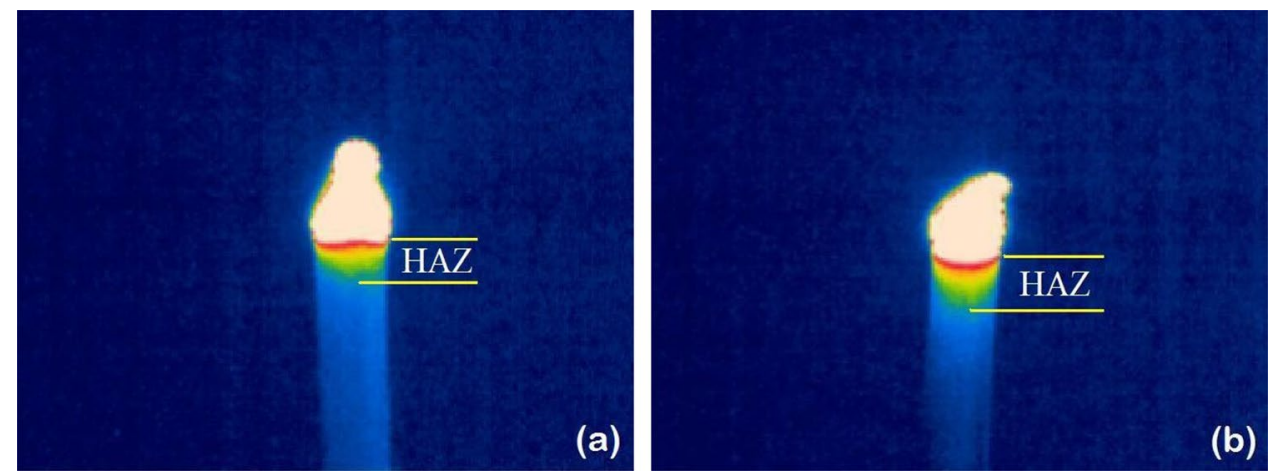

Fig. 15 FLIR for HAZ of (a) extruded plasticized poly(vinyl chloride) basic formulation, (b) rolled plasticized poly(vinyl chloride) basic formulation
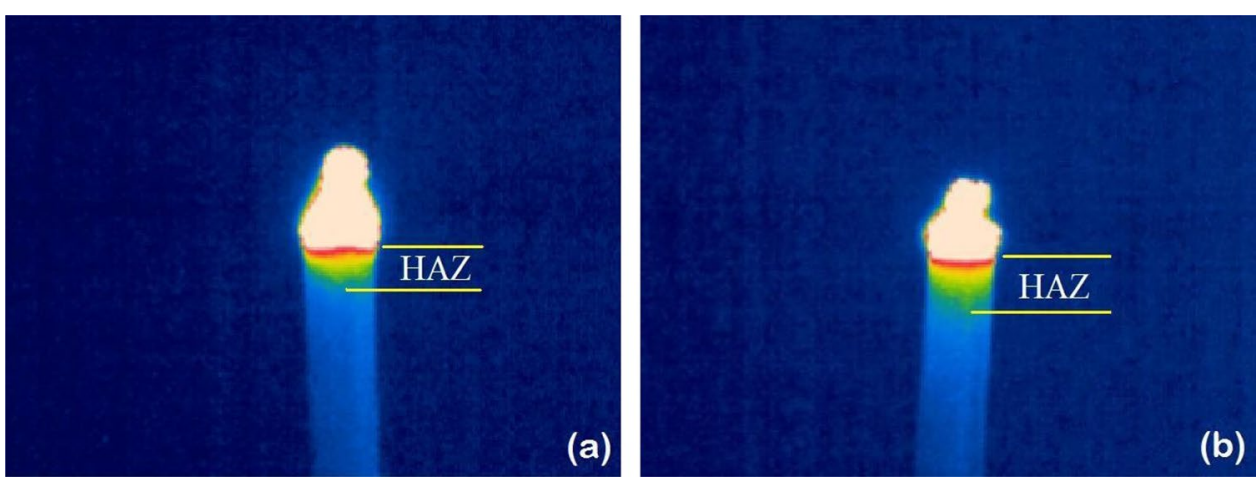

\section{Conclusions}

The critical points obtained from the tests performed on plasticized poly(vinyl chloride) (basic formulation and containing Oxydtron) will be summarized. Using Oxydtron for the first time as a poly(vinyl chloride) stabilizer and flame retardant agent with highly efficient thermal stabilizing. Oxydtron was used first time as a flame retardant agent in plasticized poly(vinyl chloride) compounds. It was discovered that Oxydtron is also a highly efficient thermal stabilizer. This stabilizing-flame retarding synergistic effect created by Oxydtron additives was unexpected behavior of a material used as a cement additive just for construction purposes. The performance of plasticized poly(vinyl chloride) at high temperatures also improved significantly using Oxydtron additive. Oxydtron additives significantly improved the poly(vinyl chloride) melt elasticity even at low concentrations, e.g., $1 \%$. The Oxydtron minimized the Bagley correction drop, which means the poly(vinyl chloride) flowability was improved. And Bagley correction values will decrease with increasing temperature. Since the Oxydtron works to shift the glass transition temperatures of poly(vinyl chloride) to higher levels, which affects kinetic energy and segmental movement, so the relaxation time will increase. The combustion of PVC is not limited to the exposed flame layer but continues beyond the combustion layer. Experiments have shown a decrease in chlorine content in the heat-affected non-burning zone. In the absence of Oxydtron, heat affected zone will ignite easily due to structural changes. The analysis of this zone proved to be important in assessing thermal stability. The high volume resistivity will improve the insulation resistance and flame retardancy of the cable cover.

Funding Open access funding provided by University of Miskolc.

\section{Declarations}

Conflicts of interest The author certify that he NO affiliations with or involvement in any organization or entity with any financial interest (such as honoraria; educational grants; participation in speakers' bureaus; membership, employment, consultancies, stock ownership, or other equity interest; and expert testimony or patent-licensing arrangements), or non-financial interest (such as personal or professional relationships, affiliations, knowledge or beliefs) in the subject matter or materials discussed in this manuscript.

Open Access This article is licensed under a Creative Commons Attribution 4.0 International License, which permits use, sharing, adaptation, distribution and reproduction in any medium or format, as long as you give appropriate credit to the original author(s) and the source, provide a link to the Creative Commons licence, and indicate if changes were made. The images or other third party material in this article are included in the article's Creative Commons licence, unless indicated 
otherwise in a credit line to the material. If material is not included in the article's Creative Commons licence and your intended use is not permitted by statutory regulation or exceeds the permitted use, you will need to obtain permission directly from the copyright holder. To view a copy of this licence, visit http://creativecommons.org/licenses/by/4.0/.

\section{References}

1. Al-Mosawi AI, Marossy K (2020) Heavy Metal Free Thermal Stabilizing-flame Retarding Modifier for Plasticized Poly(vinyl chloride). Materials Research Express Vol.7, Issue. 1 pp 015320 (11 pages). https://doi.org/10.1088/2053-1591/ ab6249

2. Al-Mosawi AI, Marossy K (2020) Elimination of plasticized poly(vinyl chloride) degradability by using oxydtron: a novel study. ARPN Journal of Engineering and Applied Sciences 15(3):405-411

3. Ye F, Ye Q, Zhan H, Ge Y, Ma X, Xu Y, Wang X (2019) Synthesis and study of zinc orotate and its synergistic effect with commercial stabilizers for stabilizing poly(vinyl chloride). Polymers Vol.11, Issue. 2, pp 194 (16 pages). https://doi.org/10.3390/polym11020194

4. Santamaría E, Edge M, Allen NS, Harvey HB, Mellor M, Orchison J (2005) New Insights into the Degradation Mechanism of Poly (vinyl chloride), Part (III): Implementation of New CostabilizersTowards Heavy Metal Free Systems (HMFS). J Appl Polym Sci 96(1):122-143. https://doi.org/10.1002/app.21414

5. Li M, Zhang J, Xin J, Huang K, Li S, Wang M, Xia J (2017) Design of green zinc-based thermal stabilizers derived from tung oil fatty acid and study of thermal stabilization for PVC. J Appl Polym Sci 134(14):44679 (11 pages). https://doi.org/10.1002/app.44679

6. Čechová E, Vojta S, Kukučka P, Kočan A, Trnovec T, Murínová LP, De Cock M, Van de Bor M, Askevold J, Eggesbø M, Scheringer M (2017) Legacy and alternative halogenated flame retardants in human milk in Europe: Implications for children's health. Environ Int 108:137-145. https://doi.org/10.1016/j.envint. 2017.08.008

7. Casas M, Chevrier C, Den Hond E, Fernandez MF, Pierik F, Philippat C, Slama R, Toft G, Vandentorren S, Wilhelm M, Vrijheid M (2013) Exposure to brominated flame retardants, perfluorinated compounds, phthalates and phenols in European birth cohorts: ENRIECO evaluation, first human biomonitoring results, and recommendations. Int $\mathrm{J}$ Hyg Environ Health 216(3):230-242. https://doi.org/10.1016/j.ijheh.2012.05.009

8. de la Torre A, Navarro I, Sanz P, los Ángeles Martínez M (2020) Organophosphate compounds, polybrominated diphenyl ethers and novel brominated flame retardants in European indoor house dust: Use, evidence for replacements and assessment of human exposure. J Hazard Mater Vol. 382, 15 January pp 121009 (8 pages). https://doi.org/10.1016/j.jhazmat.2019.121009

9. Lee H-K, Lee S, Lim J-E, Moon H-B (2020) Legacy and Novel Flame Retardants in Water and Sediment from Highly Industrialized Bays of Korea: Occurrence Source Tracking, Decadal Time Trend, and Ecological Risks. Mar Pollut Bull 160. https://doi.org/ 10.1016/j.marpolbul.2020.111639

10. Venier M, Dove A, Romanak K, Backus S, Hites R (2014) Flame retardants and legacy chemicals in Great Lakes' water. Environ Sci Technol 48(16):9563-9572. https://doi.org/10.1021/es501509r

11. Liu J, Liang C, Peng B, Zhang YY, Liu LY, Zeng EY (2020) Legacy and alternative flame retardants in typical freshwater cultured fish ponds of South China: Implications for evolving industry and pollution control. Sci Total Environ In Press, Available online 19:143016. https://doi.org/10.1016/j.scitotenv.2020.143016
12. Zhang J, Xiaodan Wu, Guo H, Zheng X, Mai B (2020) Pollution of plastic debris and halogenated flame retardants (HFRs) in soil from an abandoned e-waste recycling site: Do plastics contribute to (HFRs) in soil? J Hazard Mater, In Press, Available online 24. https://doi.org/10.1016/j.jhazmat.2020.124649

13. Wang Y, Zhang Z, Tan F, Rodgers TF, Hou M, Yang Y, Li X (2021) Ornamental houseplants as potential biosamplers for indoor pollution of organophosphorus flame retardants. Sci Total Environ Vol 767 pp 144433. https://doi.org/10.1016/j.scitotenv.2020.144433

14. Barhoumi B, Tedetti M, Peris A, Guigue C, Aznar-Alemany Ò, Touil S, Driss MR, Eljarrat E (2020) Halogenated Flame Retardants in Atmospheric Particles from a North African Coastal City (Bizerte, Tunisia): Pollution Characteristics and Human Exposure. Atmos Pollut Res 11(4):831-840. https://doi.org/10.1016/j.apr. 2020.01.011

15. Jarosinski A, Radomski P, Lelek L, Kulczycka J (2020) New production route of magnesium hydroxide and related environmental impact. Sustainability 2020, Vol.12, Issue. 21, pp 8822 (14 pages). https://doi.org/10.3390/su12218822

16. Gebke S, Thümmler K, Sonnier R, Tech S, Wagenführ A, Fischer S (2020) Suitability and modification of different renewable materials as feedstock for sustainable flame retardants. Molecules Vol 25, Issue 21, pp 5122 (13 pages). https://doi.org/10.3390/molecules 25215122

17. González-Rubio S, Ballesteros-Gómez A, Asimakopoulos AG, Jaspers VL (2021) A review on Contaminants of Emerging Concern in European Raptors (2002-2020). Sci Total Environ Vol. 760, pp 143337 (17 pages). https://doi.org/10.1016/j.scitotenv.2020.143337

18. Regulation (EC) No 1272 (2008) European parliament and of the council of 16 December 2008 on classification, labelling and packaging of substances and mixtures, amending and repealing Directives 67/548/EEC and 1999/45/EC, and amending Regulation (EC) No 1907/2006. Off J Eur Union Vol 51, 31 Dec 2008.

19. Hilado CJ (1998) Flammability handbook for plastics, 5th Edition, CRC Press. https://doi.org/10.1201/9780585248684

20. Zhang AN, Zhao HB, Cheng JB, Li ME, Li SL, Cao M, Wang YZ (2021) Construction Of durable eco-friendly biomass-based flame-retardant coating for cotton fabrics. Chem Eng J Vol 410 pp 128361. https://doi.org/10.1016/j.cej.2020.128361

21. Li N, Ming J, Yuan R, Fan S, Liu L, Li F, Wang X, Jianyong Y, Dequn W (2020) Novel Eco-Friendly Flame Retardants Based on Nitrogen-Silicone Schiff Base and Application in Cellulose. ACS Sustain Chem Eng 8(1):290-301. https://doi.org/10.1021/ acssuschemeng.9b05338

22. Kausar A (2019) Fire Protection: Flame-Retardant Polymers in, Chapter 61, In: Mishra, M. (ed.) Encyclopedia of Polymer Applications, First Edition, CRC Press, Taylor \& Francis Group, USA, pp 1258-1272. https://doi.org/10.1201/9781351019422-140000019

23. Conroy G (1999) New alternatives for environmentally friendly heat stabilizers. Plast Technol

24. Asawakosinchai A, Jubsilp C, Rimdusit S (2015) Organic based heat stabilizers for PVC: A safer and more environmentally friendly alternatives key. Eng Mater 659:321-326 https://doi. org/10.4028/www.scientific.net/KEM.659.321

25. ISO 11443:2014 (2014) Plastics-determination of the fluidity of plastics using capillary and slit-die rheometers. International Organization for Standardization (ISO)

26. ISO 4589-2:2017 (2017) Plastics - Determination of burning behaviour by oxygen index - part 2: Ambient-temperature test. International Organization for Standardization (ISO)

27. ISO 6721-11 (2012) Plastics-determination of dynamic mechanical properties - part 11: Glass transition temperature. International Organization for Standardization (ISO)

28. ASTM D257-14 (2021) e1. Standard Test Methods for DC Resistance or Conductance of Insulating Materials. ASTM International, West Conshohocken, PA 
29. Aho J, Syrjälä $S$ (2006) Determination of the entrance pressure drop in capillary rheometry using bagley correction and zero-length capillary. Annual transactions of the Nordic Rheology Society Vol 14

30. Aho J, Syrjälä S (2008) Evaluation of different methods for determining the entrance pressure drop in capillary rheometry. Appl Rheol Vol 18, Issue 6 Published online: 12 Jun 2019, pp 63258 (5 pages). https://doi.org/10.1515/arh-2008-0022

31. Werkstoff-Prüfmaschinen G (2020) Bagley correction, technical report, Buchen, Germany

32. Polychronopoulos ND, Vlachopoulos J (2019) Polymer processing and rheology, Chapter 4, In: Jafar Mazumder, M., Sheardown, H., Al-Ahmed, A. (eds.) Functional Polymers. Polymers and Polymeric Composites: A Reference Series. Springer, Cham pp 133-180. https://doi.org/10.1007/ 978-3-319-95987-0_4

33. Hyvärinen M, Jabeen R, Kärki T (2020) The Modelling of Extrusion Processes for Polymers-A Review. Polymers 12(6):1306 (14 page). https://doi.org/10.3390/polym12061306

34. Kelly AL (1998) On-line shear and extensional rheometry of polymer melts in the extrusion process, $\mathrm{PhD}$ thesis, University of Bradford, UK

35. Wagner Jr JR, Mount III EM, Giles Jr HF (2014) Shear Rate, Pressure Drop, and Other Extruder Calculations, Chapter 17, In: Wagner, J., Mount, E., and Giles, H. (eds.) Extrusion: The Definitive Processing Guide and Handbook, 2nd Edition, William Andrew, USA pp 203-206. https://doi.org/10.1016/B978-1-43773481-2.00017-X

36. Mazzanti V, Mollica F (2020) A review of wood polymer composites rheology and its implications for processing. Polymers Vol 12 Issue 10 pp 2304 (23 page). https://doi.org/10.3390/polym12102304

37. Swallowe GM (1999) Relaxations in polymers, In: Swallowe G.M. (eds) mechanical properties and testing of polymers. Polym Sci Technol Series Vol 3, Springer, Dordrecht pp 195-198. https:// doi.org/10.1007/978-94-015-9231-4_42

38. Roland CM, Archer LA, Mott PH, Sanchez-Reyes J (2004) Determining Rouse Relaxation Times from the Dynamic Modulus of Entangled Polymers. J Rheol 48(2):395-403. https://doi.org/10. $1122 / 1.1645516$

39. Boyd R, Smith G (2007) Polymer Dynamics and Relaxation, 1st edn. Cambridge University Press, UK

40. Marossy K (2006) Testing polymer mixtures by dynamic mechanical analysis. Manuscript of a lecture: Hungarian Academy of Sciences

41. Souza RE, Silveira FH, Gomes RM, Lima GS, De Conti A, Visacro S (2019) Characterization of the Effect of the Insulating
Material of Covered Cables on the Impulse Breakdown Behavior of Single- and Three-Phase Compact Distribution Lines. Electr Power Syst Res 172:161-166. https://doi.org/10.1016/j.epsr.2019. 02.017

42. Fozard B, Sheldon RP, Wright PC (1978) The DC Volume Resistivity of Plasticized PVC. J Appl Polym Sci 22(5):1167-1176. https://doi.org/10.1002/app.1978.070220501

43. Quennehen P et al (2011) Analysis of the resistivity loss of aged PVC cables and effects on their dielectric strength, 8th International Conference on Insulated Power Cables (Jicable'11), Paris, Versailles, France 19-23

44. Al-Mosawi AI, Marossy K (2018) L.O.I and DSC analyses of antimony trioxide containing plasticised $\mathrm{PVC}$ as a function of processing method, MultiScience - XXXII. microCAD International Multidisciplinary Scientific Conference 5-6 September University of Miskolc, Hungary pp 1-5. https://doi.org/10.26649/musci. 2018.017

45. Zeng D, Su PP, Madan R, Wang Y (2021) Evaluation of Flammability and Smoke Corrosivity of Data/Power Cables Used in Data Centers. Fire Saf J 120. https://doi.org/10.1016/j.firesaf. 2020.103094

46. Al-Mosawi AI, Marossy K (2017) Performance evaluation of mixing mechanism and its effects on thermal behaviour of plasticised PVC. Int J Eng Technol (IJET) Vol 9 No 6 pp 4389-4396. https:// doi.org/10.21817/ijet/2017/v9i6/170906130

47. Hobbs CE (2019) Recent advances in bio-based flame retardant additives for synthetic polymeric materials. Polymers Vol 11 Issue $2 \mathrm{pp}$ 229 (31 pages). https://doi.org/10.3390/polym11020224

48. Basfar AA (2003) Effect of various combinations of flameretardant fillers on flammability of radiation cross-linked poly(vinyl chloride) (PVC). Polym Degrad Stab Vol 82 Issue 2 pp 333-340. https://doi.org/10.1016/S0141-3910(03)00188-5

49. Troitzsch J, Antonatus E (2021) Plastics flammability handbook: principles, regulations, testing, and approval, 4th edition, Hanser Publishers, Munich, Germany. https://doi.org/10.3139/ 9781569907634.fm

50. Al-Mosawi AI, Marossy K (2018) Heat effected zone in unburned, antimony trioxide containing plasticized poly(vinyl chloride). Építóanyag-Journal of Silicate Based and Composite Materials Vol 70 No 3 pp 86-89. https://doi.org/10.14382/epitoanyag-jsbcm. 2018.16

Publisher's Note Springer Nature remains neutral with regard to jurisdictional claims in published maps and institutional affiliations. 